\title{
MORPHOLOGICAL AND ACOUSTIC IDENTIFICATION OF HIPPOSIDERIDS (Chiroptera: Hipposideridae) FROM XUAN SON NATIONAL PARK, NORTHEASTERN VIETNAM
}

\author{
Vu Dinh Thong \\ Institute of Ecology and Biological Resources, VAST
}

\begin{abstract}
Xuan Son National Park is a well known locality in Vietnam for its karst landscape and biodiversity values. The park contains a large number of caves, which are homes to 20 bat species belonging to 13 genera, four families. Of which, four species, viz. Aselliscus stoliczkanus, Hipposideros armiger, H. larvatus and H. pomona, belong to the family Hipposideridae. Prior to 2010, almost all bat researches at the park focused on taxonomy. Between 2011 and 2015, the author conducted a series of field surveys with emphases on both taxonomy and echolocation of hipposiderids. External measurements of every captured bat were taken for taxonomic assessments. Echolocation calls were recorded from natural habitats while bats flying and different situations inside a flight-tent. Results from the surveys indicated that, within Xuan Son National Park, each hipposiderid species is clearly distinguishable from the remainders of the family Hipposideridae in both morphology and echolocation frequency. This paper provides acoustic and morphological diagnoses of hipposiderids for practical monitoring, further studies and conservation of hipposiderids at the park in the future.
\end{abstract}

Keywords: Bat, conservation, mammalia, monitoring, morphology, taxonomy.

Citation: $\mathrm{Vu}$ Dinh Thong, 2016. Morphological and acoustic identification of hipposiderids (Chiroptera: Hipposideridae) from Xuan Son national park, Northeastern Vietnam. Tap chi Sinh hoc, 38(3): 298-303. DOI: 10.15625/0866-7160/v38n3.8351.

*Corresponding author: vudinhthong@hotmail.com.

\section{INTRODUCTION}

Hipposiderid is a common name of bat species belonging to the family Hipposideridae. To date, the family comprises 90 species belonging to 17 genera [20, 25]. In Vietnam, hipposiderids consist of 20 species belonging to three genera: Aselliscus, Coelops and Hipposideros [4, 6, 11, 13, 19, 20, 21, 25]. Vu Dinh Thong (2011) [20] indicated that echolocation frequency of hipposiderids and rhinolophids of Vietnam is generally specific to either species or species complex, particularly within a locality. For example, the constant frequency of the second harmonic of each echolocation calls of these bat species from Tam Dao National Park are clearly distinguishable for identification in the field [22].

Xuan Son National Park contains a large area of karst landscape with a system of caves, which is home to a highly diverse bat fauna [1]. Prior to the present study, a series of bat inventories were carried out in the park $[1,8]$. Number of bat species recorded over the surveys were impressively increased. Between 2002 and 2015, the author conducted eight field surveys throughout the park. Results from the surveys included taxonomic materials and echolocation data of four hipposiderid species. This paper provides both morphological and acoustic diagnoses of each species to strengthen forthcoming research, monitoring and conservation actions at the park in the future.

\section{MATERIALS AND METHODS}

\section{Bat capture and identification}

Field surveys were conducted at almost all known caves and footpaths under forest canopy of Xuan Son National Park $\left(21^{\circ} 03^{\prime}-21^{\circ} 12^{\prime} \mathrm{N}\right.$, $\left.104^{\circ} 51^{\prime}-105^{\circ} 01^{\prime} \mathrm{E}\right)$. With a total of 15,048 ha, the park's elevation ranges from c.200 to 1,386 $\mathrm{m}$ at the summit of a mountain peak, namely 
Voi [1]. The natural vegetation types of the park comprise montane evergreen forest and montane limestone forests [1]. Bats were captured and handled in the field following the guidelines approved by the American Society of Mammalogists [18]. Four-bank harp traps [9] and mist nets of various sizes (2.6 $\mathrm{m}$ [height], 3$12 \mathrm{~m}$ [length], mesh size: $16 \mathrm{~mm} \times 16 \mathrm{~mm}$ ) were employed to capture bats. Each captured bat was removed carefully from the trap or net and placed individually in a cotton bag. External measurements were taken following Bates \& Harrison (1997) [3], Csorba et al. (2003) [7], Vu Dinh Thong (2011) [20]. The measurements comprise FA, forearm lengthfrom the extremity of the elbow to the extremity of the carpus with the wings folded; EH, ear height of ear conch, from the base of the outer edge to the tip; TIB, tibia length-from the knee joint to the ankle; HF, hind-foot length-from the extremity of the heel behind the os calcis to the extremity of the longest digit, excluding the hairs or claws; Tail: tail length, from the tip of the tail to its base adjacent to the body. Reproductive status and age were assessed following Racey (2009) [16] and BrunetRossinni and Wilkinson (2009) [5], respectively. During this study, bats were categorized into two broad age groups, juveniles and adults, following Barlow (1999) [1].

\section{Echolocation recordings and analyses}

Sound recordings were carried out at the main entrance of caves and under forest canopies to obtain echolocation calls when bats were emerging from roosts and flying in natural habitats at night, respectively. Echolocation calls of every captured bat were recorded in different situations, when it was handheld and released inside a flight tent $(4 \mathrm{~m}$ [length] $\times 4 \mathrm{~m}$ [width] $\times 2 \mathrm{~m}$ [height]) using a PCTape system with a sampling rate of $480 \mathrm{kHz}$. Batman software, which displays color sonograms of the detected echolocation signals in real time, was used to obtain high quality sound sequences. All echolocation signals from the recordings were analysed using Selena software to measure the constant frequency of the second harmonic (CF2) of each call [20]. The PCTape system, Batman and Selena software are custom-made by the University of Tübingen, Germany, using a 512-size Fast Fourier Transformation. Recordings from natural habitats were compared with the calls of captured bats for identification based upon the CF2 values.

\section{RESULTS AND DISCUSSION}

A total of 33 adult individuals belonging to four species were captured over the surveys. Their external and acoustic measurements are given in the table 1. Morphological and acoustic features of each species are briefly described as follows:

Aselliscus stoliczkanus. This is a small species of the family Hipposideridae. Aselliscus is distinguishable from the two remaining hipposiderid genera (Coelops and Hipposideros) in Vietnam by its noseleaf structure. The upper part of the posterior leaf is divided into three lobes. Three individuals of $A$. stoliczkanus were captured at the Lang Cave in XSNP. The average forearm length of these individuals is $43.3 \mathrm{~mm}(43.0-43.7 \mathrm{~mm})$. The anterior noseleaf structure of the species includes two supplementary leaflets. Of which, the outer is shorter than the inner (fig. 1A). Each echolocation signal consists of two segments at the second harmonic, namely "constant frequency" (CF) and "terminal frequency-modulated" (tFM) (fig. 2A). Frequency value range for $\mathrm{CF} 2$ of the captured individuals is $130.2-131.4 \mathrm{kHz}$ (table 1).

Hipposideros armiger. Seven individuals of this species were captured at an unnamed cave close to Du village. An average forearm length of these individuals is $92.4 \mathrm{~mm}(89.4-95.4 \mathrm{~mm})$. The anterior noseleaf structure of the species includes four supplementary leaflets. Of which, the outmost one is less developed and much smaller than the three remainders (fig. 1B). Each echolocation signal consists of two segments at the second harmonic: $\mathrm{CF}$ and $\mathrm{tFM}$ (fig. 2B). Frequency value range for CF2 of the captured individuals is $64.7-67.6 \mathrm{kHz}$ (table 1 ).

Hipposideros larvatus. This is one of the most common bat species in XSNP. Twenty individuals of the species were captured over the surveys. An average forearm length of these 
individuals is $59.3 \mathrm{~mm}(57.2-61.0 \mathrm{~mm})$. The anterior noseleaf of each individual has three supplementary leaflets, which are almost equal in size (fig. 1C). Each echolocation signal consists of two segments at the second harmonic: $\mathrm{CF}$ and tFM (fig. 2C). Frequency value range for $\mathrm{CF} 2$ of the captured individuals is $84.4-87.7 \mathrm{kHz}$ (table 1 ).

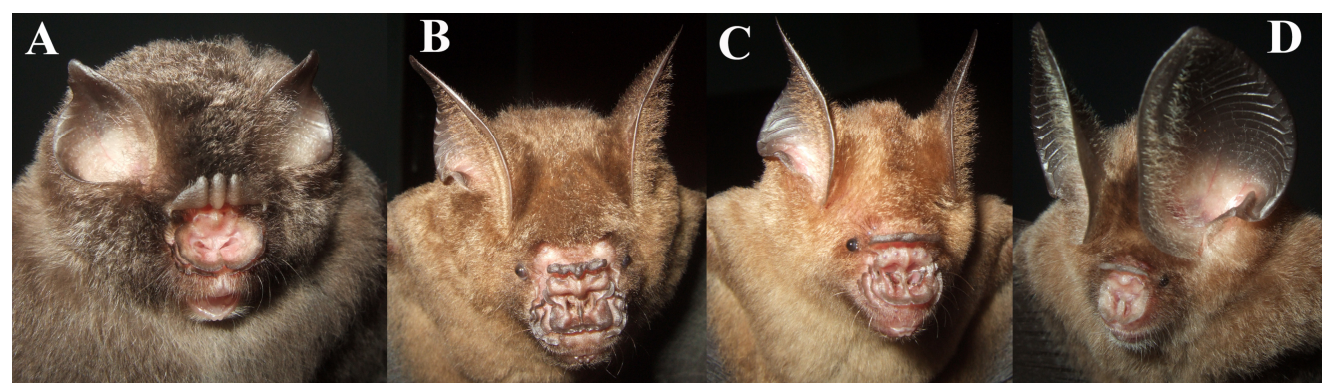

Figure 1. Ear and face of leaf-nosed bat species from XSNP. A = Aselliscus stoliczkanus; $B=$ Hipposideros armiger; $\mathrm{C}=H$. larvatus; $\mathrm{D}=H$. pomona.

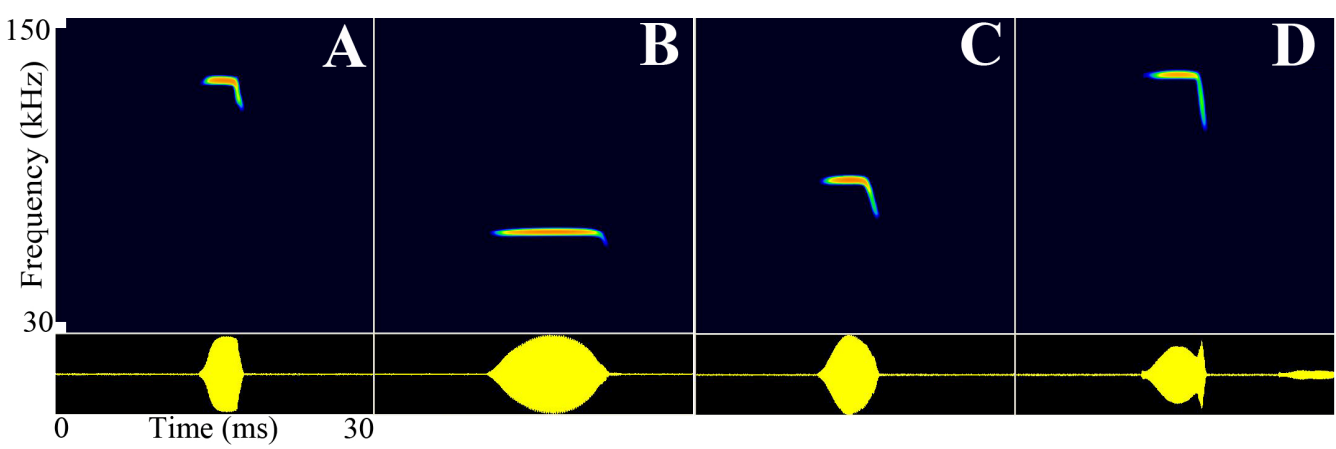

Figure 2. Typical echolocation signals of four lhipposiderid species from Xuan Son National Park, calls are shown in spectrogram (top) and oscillogram (bottom): $\mathrm{A}=$ A. stoliczkanus; $\mathrm{B}=H$. armiger; $\mathrm{C}=H$. larvatus; $\mathrm{D}=H$. pomona

Table 1. Morphological measurements (in $\mathrm{mm}$ ) and CF2 (in $\mathrm{kHz}$ ) of four hipposiderid species from Xuan Son National Park

\begin{tabular}{|c|c|c|c|c|c|c|c|}
\hline \multirow{2}{*}{ Species } & \multirow{2}{*}{$\mathrm{n}$} & \multicolumn{6}{|c|}{ Measurement and echolocation frequency } \\
\hline & & FA & EH & TIB & $\mathrm{HF}$ & Tail & CF2 \\
\hline A. stoliczkanus & 3 & $\begin{array}{l}43.3 \pm 0.4 \\
43.0-43.7\end{array}$ & $\begin{array}{l}8.6 \pm 0.6 \\
8.0-9.1\end{array}$ & $\mathrm{n} / \mathrm{a}$ & $\mathrm{n} / \mathrm{a}$ & $\mathrm{n} / \mathrm{a}$ & $\begin{array}{c}130.7 \pm 0.6 \\
130.2-131.4\end{array}$ \\
\hline H. armiger & 7 & $\begin{array}{l}92.4 \pm 1.9 \\
89.4-95.4\end{array}$ & $\begin{array}{c}32.1 \pm 1.0 \\
30.0-33.0\end{array}$ & $\mathrm{n} / \mathrm{a}$ & $\mathrm{n} / \mathrm{a}$ & $\mathrm{n} / \mathrm{a}$ & $\begin{array}{c}66.3 \pm 1.2 \\
64.7-67.6\end{array}$ \\
\hline H. larvatus & 20 & $\begin{array}{l}59.3 \pm 1.0 \\
57.2-61.0\end{array}$ & $\begin{array}{l}22.4 \pm 0.6 \\
21.0-23.0\end{array}$ & $24.3,24.4(2)$ & $9.5,9.8(2)$ & $36.0,40.0(2)$ & $\begin{array}{c}86.3 \pm 0.9 \\
84.4-87.7\end{array}$ \\
\hline H. pomona & 3 & $\begin{array}{l}42.4 \pm 0.4 \\
42.0-42.6\end{array}$ & $\begin{array}{l}21.6 \pm 1.2 \\
20.6-23.0\end{array}$ & $19.1(1)$ & $6.9(1)$ & $37.0(1)$ & $\begin{array}{c}121.9 \pm 0.7 \\
121.1-121.5\end{array}$ \\
\hline
\end{tabular}

Note: $\mathrm{n}=$ sample size of captured individuals and representative CF2 of each individual. FA, EH, TIB, HF, Tail and CF2 are defined in the section "Materials and Methods"; n/a = not available. Values are given as mean \pm standard deviation, minimum-maximum, sample size (number of captured bats) in parentheses.

Hipposideros pomona. This was rarely individuals of the species were captured at the recorded during the surveys at XSNP. Three Lang Cave. An average forearm length of these 
individuals is $42.4 \mathrm{~mm}(42.0-42.6 \mathrm{~mm})$. The noseleaf structure of each individual is simple without supplementary leaflet (fig. 1D). Each echolocation signal consists of two segments at the second harmonic: CF and tFM (fig. 2D). Frequency value range for $\mathrm{CF} 2$ of the captured individuals is $121.1-121.5 \mathrm{kHz}$ (table 1).

Within XSNP, frequency values for CF2 of each hipposiderid species are distinguishable from those of the remaining ones. Results from the present study support the roles of echolocation research in monitoring of bats in Vietnam [10]. The CF2 values of hipposiderids from XSNP are similar to those of hipposiderids from Kim Hy Nature Reserve and Tam Dao National Park (table 2).

The constant frequency of the second harmonic is an essential character in echolocation research of bat species belonging to two families: Hipposideridae and Rhinolophidae, except Coelops frithii typically use calls dominated at the tFM [12]. In the world, CF2 has been a key diagnose for acoustic identification of hipposiderids and rhinolophids in Cambodia, India, Swaziland and other countries [14, 15, 26]. Remarkably, some species vary echolocation frequency among age classes and geographically at both national and regional scales [20, 21, 22]. Therefore, Vu Dinh Thong (2014b) noted that "acoustic identification of bats requires expert background in bat echolocation research with serious attention to both recordings and examination of sound parameters" [22].

Table 2. A comparison of the CF2 values (in $\mathrm{kHz}$ ) of hipposiderids from Xuan Son National Park and two other localities in Vietnam

\begin{tabular}{|c|c|c|c|}
\hline Species & $\begin{array}{c}\text { Xuan Son National } \\
\text { Park }\end{array}$ & $\begin{array}{c}\text { Tam Dao National Park } \\
{[22]}\end{array}$ & $\begin{array}{l}\text { Kim Hy Nature } \\
\text { Reserve }[10]^{*}\end{array}$ \\
\hline A. stoloczkanus & $130.2-131.4$ & $\mathrm{n} / \mathrm{a}$ & $124.3-130.8$ \\
\hline H. armiger & $64.7-67.6$ & $64.9-65.9$ & $63.2-66.8$ \\
\hline H. larvatus & 84.4-87.7 & 85.9-88.2 & 83.8-89.3 \\
\hline H. pomona & $121.1-121.5$ & $128.2-129.1$ & $122.0-127.7$ \\
\hline
\end{tabular}

Note: $(n / a)=$ not available. * Data presented by the authors is the frequency with maximum of a single call, which is approximate to the CF measure in this study.

\section{CONCLUSION}

Xuan Son National Park is a home to four species of the family Hipposideridae: Aselliscus stoliczkanus, Hipposideros armiger, H. larvatus and $H$. pomona. Their echolocation frequencies and morphological parameters are specific to species. Therefore, each of the four species is clearly distinguishable from the remainders in both morphology and echolocation call frequency.

Acknowledgements: This research is funded by the Vietnam National Foundation for Science and Technology Development (NAFOSTED) under grant number 106.11-2012.02. The author is very grateful to Prof. Hans-Ulrich Schnitzler, Dr. Annette Denzinger, Dr. Christian Dietz of the University of Tuebingen, Germany; Dr Paul J.J. Bates and Dr. David L. Harrison of the
Harrison Institute, England; Prof. Paul Racey of the University of Exeter, England; Dr. Neil Furey of the Fauna and Flora International (Cambodia); Dr. Tigga Kingston of the Texas Tech University (USA); and to our colleagues at the Institute of Ecology and Biological Resources and other institutions for their help and support.

\section{REFERENCES}

1. Anon, 1995. Investment plan for Xuan Son Nature Reserve and buffer zone. Viet Tri: North-astern Sub-FIPI. In Vietnamese.

2. Barlow K., 1999. Expedition Field Techniques: Bats. Royal Geographical Society with IBG, 1 Kensington Gore, London SW7 2AR, England, 73pp. 
3. Bates P. J. J., Harrison D. L., 1997. Bats of the Indian Subcontinent. Harrison Zoological Museum, Sevenoaks, Kent, United Kingdom, 297 pp.

4. Borissenko A. V., Kruskop S. V., 2003. Bats of Vietnam and Adjacent Territories: an identification manual. Joint RussianVietnamese Science and Technological Tropical Centre, Moscow and Hanoi, Russia and Vietnam, 212 pp.

5. Brunet-Rossinni A. K., Wilkinson G. S., 2009. Methods for age estimation and the study of senescence in bats. In: Kunz T. H., Parsons S. (eds.) Ecological and Behavioral Methods for the Study of Bats, 2nd edition, Johns Hopkins University Press, Baltimore, pp. 315-325.

6. Corbet G. B., Hill J. E., 1992. The Mammals of the Indomalayan Region. Oxford University Press, Oxford, England, $496 \mathrm{pp}$.

7. Csorba G., Ujhelyi P., Thomas N., 2003. Horseshoe Bats of the World (Chiroptera: Rhinolophidae). Alana Books, England, 160 pp.

8. Nguyen Xuan Dang, 2006. Species composition and conservation values of mammal fauna in the Xuan Son National Park, Phu Tho province. Tap chi Sinh hoc, 28(1): 47-53.

9. Francis C. M., 1989. A comparison of mist nets and two types of harp traps for capturing bats. Journal of Mammalogy, 70: 865-870.

10. Furey N. M., Mackie I. J., Racey P. A., 2009. The role of ultrasonic bat detectors in improving inventory and monitoring surveys in Vietnamese karst bat assemblages. Current Zoology, 55(5): 327 341.

11. Hendrichsen D. K., Bates P. J. J., Hayes B. D., Walson J. L., 2001. Recent records of bats (Mammalia: Chiroptera) from Vietnam with six species new to the country. Myotis, 39: 35-199.

12. Ho, Y.-Y., Fang Y.-P., Chou C.-H., Cheng
H.-C., Chang H.-W., 2013. High Duty Cycle to Low Duty Cycle: Echolocation Behaviour of the Hipposiderid Bat Coelops frithii. PLOS one, 8(5): 1-7.

13. Kruskop S. V., 2013. Bats of Vietnam: Checklist and an identification manual. Moscow, Russia, 299 pp.

14. Monadjem, A., Reside A., Lumsden L., 2007. Echolocation calls of rhinolophid and hipposiderid bats in Swaziland. South African Journal of Wildlife Research, 37(1): 9-15.

15. Phauk S., Phen S. Furey N.M., 2013. Cambodian bat echolocation: a first description of assemblage call parameters and assessment of their utility for species identification. Cambodian Journal of Natural History, 2013, 16-26.

16. Racey P. A., 2009. Reproductive assessment in bats. In: Kunz T.H., Parsons S. (eds.) Ecological and Behavioral Methods for the Study of Bats, 2nd edition, Johns Hopkins University Press, Baltimore, pp. 249-264.

17. Saveng S., Bumrungsri S., Furey N. M., Bates P. J. J., Wonglapsuwan M., Khan F. A. A., $\mathrm{Vu}$ Dinh Thong, Soisook P., Satasook C., Thomas N. M., 2015. Taxonomic implications of geographical variation in Rhinolophus affinis (Chiroptera: Rhinolophidae) in mainland Southeast Asia. Zoological Studies, 54(31): 1-29.

18. Sikes R. S., William L. Gannon, The Animal Care and Use Committeel of The American Society of Mammalogists, 2011. Guidelines of the American Society of Mammalogists for the use of wild mammals in research. Journal of Mammalogy, 92(1): 235-253.

19. Simmons N. B., 2005. Order Chiroptera. In: Wilson DE and Reeder DM (eds.) Mammal species of the world: A taxonomic and geographic reference. The Johns Hopkins University Press, Baltimore, 3rd edition, pp. 312-529.

20. Vu Dinh Thong, 2011. Systematics and echolocation of rhinolophoid bats (Mammalia: Chiroptera) in Vietnam. PhD 
Thesis, University of Tuebingen, Tuebingen, Germany, 258 pp.

21. Vu Dinh Thong, 2014a. Acoustic identification and taxonomic remarks of horseshoe bats (Chiroptera: Rhinolophidae) in Cat $\mathrm{Ba}$ National Park, northeastern Vietnam. Proceedings of the first VASTBAS workshop on science and technology, Ha Long city, Vietnam: 323-328.

22. Vu Dinh Thong, 2014b. Acoustic identification and taxonomic remarks of hipposiderids and rhinolophids (Chiroptera: Hipposideridae, Rhinolophidae) in Tam Dao National Park, northeastern Vietnam. Tap chi Sinh hoc, 36(4): 487-493.

23. Pham Duc Tien, T.M. Hoi, N.T. Son, Vu Dinh Thong, 2004. Results of a bat survey in Xuan Son National Park. Issues of basic research in life sciences, Proceedings of the
2004 national conference on life sciences. Science and Technics Publishing House: 267-270 (in Vietnamese).

24. Pham Duc Tien, Vu Dinh Thong, Le Vu Khoi, 2005. Current status of bats at Xuan Son National Park. Proceedings of the 2005 national conference on life sciences. Science and Technics Publishing House: 320-323 (in Vietnamese).

25. Vuong Tan Tu, Csorba G., Gorfol T., Arai S., Son N. T., Thanh H. T., Hasanin A., 2015. Description of a new species of the genus Aselliscus (Chiroptera, Hipposideridae) from Vietnam. Acta Chiropterologica, 17(2): 233-254.

26. Wordley C. F. R., Foui E. K., Mudappa D., Sankaran M., Altringham J. D., 2014. Acoustic identification of bats in the southern Western Ghats, India. Acta Chiropterologica, 16(1): 213-222.

\title{
ĐẶC ĐIỂM HÌNH THÁI PHÂN LOẠI VÀ TIẾNG KÊU SIÊU ÂM CỦA CÁC LOÀI DƠI NẾP MŨI (Chiroptera: Hipposideridae) Ở VƯờN QUỐC GIA XUÂN SƠN, VÙNG ĐÔNG BẮC VIỆT NAM
}

\author{
Vũ Đình Thống \\ Viện Sinh thái và Tài nguyên sinh vật, Viện Hàn lâm KH \& CN Việt Nam
}

\section{TÓM TÁ̀T}

Vườn quốc gia Xuân Sơn là địa danh được biết đến nhiều ở Việt Nam về cảnh quan núi đá vôi và giá trị đa dạng sinh học. Vườn quốc gia có nhiều hang động, hiện là nơi sinh sống của 20 loài dơi thuộc 13 giống, 4 họ. Trong đó, có 4 loài, Aselliscus stoliczkanus, Hipposideros armiger, H. larvatus và H. pomona, thuộc họ Hipposideridae. Trước năm 2010, hầu hết những nghiên cứu về dơi ở vườn quốc gia này mới chỉ tập trung vào hình thái phân loại. Từ năm 2011 đến 2015, tác giả đã thực hiện nhiều đợt điều tra thực địa với nội dung nghiên cứu tập trung vào cả đặc điểm hình thái phân loại và tiếng kêu siêu âm của các loài dơi nếp mũi. Kích thước hình thái ngoài của mỗi cá thể dơi mắc lưới hoặc bẫy được đo ngay trên thực địa làm cơ sở khoa học để định loại. Tiếng kêu siêu âm của dơi được ghi trong sinh cảnh sống tự nhiên khi dơi kiếm ăn và trong những điều kiện thí nghiệm khác nhau. Kết quả điều tra cho thấy, trong phạm vi của vườn quốc gia Xuân Sơn, mỗi loài dơi nếp mũi khác biệt rõ với các loài còn lại trong cùng họ Hipposideridae bởi cả đặc điểm hình thái và tần số siêu âm. Bài báo này cung cấp những đặc điểm đặc trưng về hình thái và âm sinh học của mỗi loài để làm cơ sở cho công tác giám sát, nghiên cứu tiếp theo và bảo tồn ở vườn quốc gia trong thời gian tới.

Từ khóa: Mammalia, bảo tồn, dơi, giám sát, hình thái học, siêu âm.

Received 22 May 2016, accepted 20 September 2016 